\title{
An Overview of Small and Medium Enterprises in Malaysia and Pakistan: Past, Present and Future Scenario
}

\author{
Muhammad Wasim Jan Khan \\ PhD Student, Faculty of Economics and Business \\ University Malaysia Sarawak, Malaysia \\ E-mail:wasimjanpk@yahoo.com \\ Dr. Muhammad Khalique \\ Senior Lecturer, Faculty of Economics and Business \\ University Malaysia Sarawak, Malaysia \\ E-mail: drmkhalique@gmail.com
}

Received: June 9, 2014 Accepted: October 24, $2014 \quad$ Published: November 21, 2014

doi:10.5296/bmh.v2i2.5792ＵRL: http://dx.doi.org/10.5296/bmh.v2i2.5792

\begin{abstract}
The main objective of this study was to identify the importance of SMEs in Malaysian and Pakistani economies. Small and Medium Enterprises (SMEs) play a vital role in the development and growth of the Malaysian and Pakistani economies. However, their contribution to the national economies of both countries is still relatively small. Malaysian and Pakistani governments have made various fundamental steps to improve the growth of SMEs. In spite of this, SMEs are still facing heaps of challenges and obstacles that deter them from further expanding their businesses and sustainable growth. This study provides the review of the importance of SMEs in Malaysia and Pakistan.
\end{abstract}

Keywords: Small and Medium Enterprises, Contributions, Challenges, Malaysia, Pakistan 


\section{Introduction}

Throughout the world the role of small and medium sized enterprises (SMEs) is becoming increasingly prominent (Veskaisri et al., 2007). SMEs can be established in any locality for any kind of business activity in urban or rural area (Khalique et al., 2011). According to Reider $(2008,17)$, the two main primary reasons for the existence of small firms are: (1) to provide goods and services to satisfy customers' needs in a manner that they will continue to use and recommend the firms' goods and services, i.e. “customer service business” and (2) to create desired goods and services so that the investment in the firm is converted to cash as quickly as possible, i.e. “cash conversion business” (Armstrong \& Drnevich, 2009).

Small businesses are very important to the world economies (Wiklund \& Shepherd, 2005). The most important and the large part of world economies are the small firms. That is why, more and more researchers are seeking and trying to understand about these firms. Even the governments of the all the economies of the globe and particularly those agencies which are responsible for the development of these firms, take deep interest in understanding about these firms (Hill \& McGowan, 1999). Small business firms play an important role in the economy of any country (Wong \& Aspinwall, 2004). In many jurisdictions, the small and medium sized enterprises (SMEs) sector has attracted increasing and significant attention from policy makers. This attention has focused on SMEs development, business birth rates and entrepreneurship in the developed economies. These economies look to the SMEs sector for provision of increased employment, economic development and innovation (Dalrymple, 2004).

According to Asia-Pacific Co-operation (APEC), 2010, in every country in the Asia-Pacific Co-operation, SMEs account for over $90 \%$ of all enterprises (Mohammad, 2012). For economies of most nations of the world, the demand of the SMEs is increasing and has become their recognized feature (Omar et al., 2009). For example, in the United States, SMEs represent an overwhelming majority of all businesses and account for almost one-half of the gross national product. SMEs in Thailand represent over 90 percent of the total number of entrepreneurs in nearly all business sectors, and employ over 60 percent of the labour force (Veskaisri et al., 2007).

The abbreviation SME is commonly used in international organizations and in European Union countries, such as the United Nations (UN), the World Bank and the World Trade Organization (WTO). The term small and medium business (SMB) is also prevailing in a few other countries of the world (Syed et al., 2012). The classification and definition of businesses are generally based on quantifiable characteristics such as number of employees, sales volume or worth of assets (Rahman, 2001). The specific definition for SMEs, used by each country in the world, is usually based on several different criteria which include sales or assets, number of employees and levels of capital, (Mohammad, 2012). No uniform definition of SMEs is available in literature. In USA, businesses having employees fewer than Five hundreds (500) are considered as SMEs. In case of European Union, businesses having less than 250 employees are considered as small and medium sized businesses (Khalique et al., 2011b). 


\section{Small and Medium Enterprises of Malaysia}

According to SME International Malaysia (2013), some advanced economies have succeeded because small and medium enterprises form a fundamental part of the economies, comprising over $98 \%$ of total establishments and contributing to over $65 \%$ of employment as well as over $50 \%$ of the gross domestic product. Although, the numbers might be lower in Malaysia, SMEs have the potential to contribute substantially to the economy and can provide a strong foundation for the growth of new industries as well as strengthening the existing ones, for Malaysia's future development. Developing stronger SMEs require major changes in the manufacturing sector, as SMEs make up over $90 \%$ of the Malaysia's manufacturing sector.

In 2011, Malaysian SMEs continued to expand at a relatively stronger pace of $6.8 \%$ and remained resilient to external environment challenges. In 2012, in line with the official GDP projection of 4.5 - 5.0\% in 2012, the Malaysian SMEs were expected to record a steady growth pace of $6.5-7.0 \%$. The latest profile of SMEs is released in September 2012 which is based on the Economic Census 2011. According to the Census, Malaysian SMEs now represent 97.3\% (645,136 establishments) of the total establishments of 662,939 in the country (SME Corp. Malaysia, 2014).

According to Dun and Bradstreet, the main focus for developing nations should be the SMEs. For the unemployment issue and the development of Malaysia's economy, small and medium enterprises (SMEs) are very important (Rose et al., 2006). In Malaysian economy, SMEs are very important and play an important role in its development (Omar et al., 2009). Small and medium enterprises (SMEs) play a vital role in the Malaysian economy and are considered to be the backbone of industrial development in the country (Saleh \& Ndubisi, 2006). The future progress of Malaysia seems to depend greatly upon development of SMEs and they are vital for accomplishing vision 2020, to be fully developed and become an industrialized nation by the year 2020. In the year 2020, Malaysia will develop to become an industrialize nation by capitalizing on the country's strengths and by overcoming weaknesses through the SMEs (Omar et al., 2009). Malaysian economy has so far significantly depended on the exports of electrical and electronics products. Since the mid-1990s, more than 50 per cent of Malaysia's exports have been electrical and electronic products. Most of these products are matured products with relatively low value-added.

Today, unlike in the 1970s and 1980s, for Malaysia, cheap labor is no longer a competitive advantage. Much cheaper labor can be found in China and Vietnam (Goh \& Lim, 2004). Over the last few decades, the Malaysian economy has undoubtedly passed through a considerable transformation from agricultural-based to industry-based. Now the economy is shifting from industry-based to a knowledge-based economy to achieve the vision 2020 and to become a developed economy (Khalique et al., 2013a).

In the Malaysian economy, the role of SMEs is considered as the backbone of the economy (Radam et al., 2008). Malaysia also experienced similar symptoms of recession as businesses were slowing down and unemployment rate climbing up like other countries, and Malaysian SMEs were hit hard. Thus, Government of Malaysia has also recognized the importance of 
SMEs for the economy and has implemented various policies, action plans and programs to assist them in these difficult circumstances (Char et al., 2010).

According to Samad (2007), competitive and resilient SMEs are important in the growth and development process of the Malaysian economy including the adoption of appropriate strategy, as SMEs have great potential to be the engine of the economic growth as could be seen in other developed countries both in East and West like Germany and Japan. Most SMEs require support or assistance from the government, especially to be more competitive in the global business environment. The strategy practices by SMEs in Malaysia are pertinent to be competitive in the global market. Malaysia also experienced similar symptoms of recession as businesses were slowing down and unemployment rate climbing up like other countries, and Malaysian SMEs were hit hard. SMEs, small in its working capital, assets and skilled workforce etc, are affected in larger degree, especially those which are involved with supplying products and trading or services to other businesses. The most important key success factor in Malaysian SMEs is "team work" (Noudoostbeni et al., 2009). Also, according to Sim (1991), Sim and Yap (1997) and hashim (2000), limited attention is given to research in the field of strategic planning, and also researchers investigating SMEs has given limited attention to strategic planning in SMEs in Malaysian context (Hin et al., 2013).

\section{Small and Medium Enterprises of Pakistan}

SMEs are playing significant role in the economic progress of Pakistan (Syed et al., 2012). According to the figures and facts provided by the UNIDO, 90 percent businesses world-wide fall into the category of SMEs sector and provides approximately 60 percent employments around the world (Khan et al., 2013). Small and medium enterprises (SMEs) play a vital role in contributing to the economies and are considered as the backbone of economic growth in developing as well as developed nations. Like other developing countries, Pakistan's economy is also largely based on SMEs (Khalique et al., 2011c).

Small and medium enterprises (SMEs) are essential to the economy of every country, particularly developing economies. SMEs are strategically important in many developing countries, particularly those located in the Asian region. SMEs are contributing significantly in Pakistan's economy since its independence (Hussain et al., 2012). Research on SMEs in Pakistani context is at initial stages. The health and performance of SMEs is at their alarming stage. Lack of intellectual capital and infrastructure, political instability, and energy crises are the general and serious threats to survival and stability of SMEs in Pakistan. Due to lack of competencies, SMEs are not able to compete at national as well as international level. Therefore, SMEs have fierce challenges for their survival in competitive environment (Khalique et al., 2011c).

In Pakistan, more than 85 per cent of the manufacturing companies can be classified as small and medium enterprises (SMEs). The remaining companies are branches of multinationals and their affiliates. SMEs are feeling a constant need to keep up with the current level of technology in a rapidly changing technological environment, thus making it essential for them to identify and apply more advanced technologies (Raouf, 1998). 
According to Bizomer (2009), in Pakistan, SMEs sector is not only the minor sharer (having small contribution) till yet in boosting the economy, but the reality is that Pakistan's whole economy is highly dependent on the pace and productivity of SMEs. Out of Pakistan's 3.2 million enterprises, 95\% are those who possess 99 employees in private industrial sector and employ about $78 \%$ of non-agricultural labor force. SMEs contribute $25 \%$ export of manufacturing goods and 30\% of GDP is the outcome of business efforts of SMEs. SMEs will be the main source of poverty reduction in Pakistan that will create the value and innovation for the country in the days to come.

According to Pakistan economic survey (2012-13), Pakistan's economy continues to face challenges like energy shortages, floods and rains, poor law and order situation, and a host of other structural impediments that have held back investment and growth in the country. The economy of Pakistan during the last five years grew on average at the rate of 2.9 percent per annum. Industrial sector contains 20.9 percent of GDP having sub sectors: manufacturing, construction, mining \& quarrying and electricity and gas distribution. Manufacturing sector has 13.2 percent share in GDP. The growth of the manufacturing sector is estimated at 3.5 percent compared to the growth of 2.1 percent last year.

In the country like Pakistan, the manufacturing sector has great potential to promoting economic growth and competiveness. It is one of the leading sectors in Pakistan. The sector has experienced the fluctuations over the years under different financial conditions. In terms of gross domestic product (GDP), the share of manufacturing sector rose in the last 10 years from 14.7 percent in 1999-2000 to 18.7 percent in 2010-11. On the other side, according to Shah (2011), investment, a "booster" of an economy, has shown a decreasing trend from 2007 to 2011 (Memon \& Tahir, 2012).

\section{Background of SMEs Corporation Malaysia}

In Malaysia on May 2nd 1996, a specialized agency known as the Small and Medium Industries Development Corporation (SMIDEC) was established to increase the development of small and medium enterprises (SMEs) by providing financial assistance, advisory services, infrastructure facilities, market access and other support programs. Its aim was to develop Malaysian SMEs to be competitive in the global market. In 2004, the establishment of the National SME Development Council (NSDC) presented another chapter in SMEs development in Malaysia. As the highest policy-making body, its role was to formulate strategies for SMEs development across all the economic sectors and related Ministries and Agencies as well as to ensure effective implementation of the overall SMEs development programs in Malaysia. In 2007, the NSDC decided to appoint a single dedicated agency to coordinate programs across all related Ministries and Agencies and to formulate overall policies and strategies for SMEs. So, SMIDEC was tasked to assume the role and the official transformation into Small and Medium Enterprise Corporation Malaysia (SMEs Corp. Malaysia) commenced on 2 October 2009. SMEs Corp. Malaysia is now the central point of reference for information and advisory services for all SMEs in Malaysia (SMEs Crop. Malaysia 2013). According to Small and Medium Enterprises Corporation Malaysia (SMEs Corp. Malaysia), Malaysian SMEs are defined as 
Manufacturing sector: sales turnover not exceeding RM 50 million or full-time employees not exceeding 200 workers (SMEs Corp. Malaysia, 2014).

Services and other sectors: sales turnover not exceeding RM 20 million or full-time employees not exceeding 75 workers (SMEs Corp. Malaysia, 2014).

Table 1. Facts and figures of SMEs in Malaysia

\section{Economic Census 2011 (Reference Year}

2010)

\begin{tabular}{lllll}
\hline No. of Establishments & Total & SMEs & \% of SMEs & $\begin{array}{l}\text { \% of SMEs over total } \\
\text { SMEs }\end{array}$ \\
\hline Services & & & & 90.0 \\
Manufacturing & 591,883 & 580,985 & 98.2 & 5.9 \\
Agriculture & 39,669 & 37,861 & 95.4 & 1.0 \\
Construction & 8,829 & 6,708 & 76.0 & 3.0 \\
Mining \& Quarrying & 22,140 & 19,283 & 87.1 & 0.1 \\
Total Establishments & 418 & 299 & 71.5 & 100 \\
\hline
\end{tabular}

Source: SMEs Annual Report Malaysia, 2011/2012.

\section{Pakistani SMEs and Supporting Institutions}

In October 1998, SMEDA was established under Ministry of Industries by the Government of Pakistan for the development of small \& medium enterprises (SMEs) in Pakistan. SMEDA is not only SME policy-advisory body for the government of Pakistan but it also provides business development services to small and medium enterprises and facilitates other stakeholders in development of their SMEs agendas in Pakistan (SMEDA, 2013). Pakistani government also established various institutions and scheme such as SMEs Banks, SMEDA, Prime Minister's youth business loan, Microloan Insurance Scheme, etc. According to SMEs Policy 2007, small and medium enterprises are defined as follow.

Table 2. Definition of SMEs in Pakistan

\begin{tabular}{lll}
\hline Enterprise Category & Employment Size (a) & Annual Sales (b) \\
\hline Small \& Medium Enterprise (SME) & Up to 250 & Up to Rs. 250 Million \\
\hline
\end{tabular}


SMEs are defined by some other institutions in Pakistan as under;

Table 3. Definition of SMEs in Pakistan by others Institutions

\begin{tabular}{lll}
\hline Institution & Small & Medium \\
\hline SME Bank & Total Assets of Rs. 20 million & Total Assets of \\
$\begin{array}{l}\text { Federal Bureau of } \\
\text { Statistics }\end{array}$ & Less than 10 employees & N/A \\
$\begin{array}{l}\text { Punjab Small Industries } \\
\text { Corporation }\end{array}$ & Fixed investment up to Rs. 20 million excluding land and building & N/A \\
Punjab Industries & Fixed assets with Rs. 10 million excluding cost of land \\
$\begin{array}{l}\text { Department } \\
\text { Sindh Industries }\end{array}$ & $\begin{array}{l}\text { Entity engaged in handicrafts or manufacturing of consumer or } \\
\text { pepartment }\end{array}$ & $\begin{array}{l}\text { producer goods with fixed capital investment up to Rs.10 million } \\
\text { including land \& building } \\
\text { An entity, ideally not being a public limited company, which does not } \\
\text { (State Bank of Pakistan }\end{array}$ \\
$\begin{array}{l}\text { employee more than 250 persons (manufacturing) and 50 persons } \\
\text { Regulations) }\end{array}$ & $\begin{array}{l}\text { (trade / services) and also fulfills one of the following criteria: } \\
\text { (1) A trade / services concern with total assets at cost excluding land } \\
\text { and buildings up to Rs 50 million. } \\
\text { (2) A manufacturing concern with total assets at cost excluding land } \\
\text { and building up to Rs 100 million. } \\
\text { (3) Any concern (trade, services or manufacturing) with net sales not } \\
\text { exceeding Rs 300 million as per latest financial statements. }\end{array}$ \\
\hline
\end{tabular}

Source: SMEDA, 2013.

So, according to SMEDA of Pakistan, we simply can say that those enterprises having annual sales up to Rs. 250 Million OR employees up to 250 are called to be the small and medium enterprises of Pakistan.

\section{Facts and Figures of SMEs in Pakistan}

According to State Bank of Pakistan (2009) \& Economic Survey of Pakistan (2009-10), the SME sector in Pakistan contributes 30\% in the GDP, along with agriculture sector provides $90 \%$ jobs, $80 \%$ of the non-agricultural workforce, makes $35 \%$ value addition in the manufacturing industry and adds $25 \%$ exports earnings in the national exchequer [up to US\$ 2.5 billion] (Qureshi, 2012).

According to the latest Economic Census of Pakistan (2005), there were 2.96 million units in Pakistan, of which 2.8 million (93.9\%) were Establishments and 0.18 million (6.1\%) were Household Units (including all activities of producing goods and services for sale or barter in the market). Punjab had the largest share of $65.26 \%$ in the total establishments in 2005, Sindh 
(17.82\%), NWFP (14.21\%), and Balochistan (2.09\%). Of the total 2.96 million Establishment and Household units, about 53\% were in the major industry group of Wholesale and Retail Trade and Hotels / Restaurants, Community, Social and Personal Services (22.3\%) (Bizomer, 2009). Manufacturing is the third largest group with $19.72 \%$ share of the total Establishments. Among the Household units, the highest share is that of manufacturing sector $(66.5 \%)$, Community, Social and Personal Services (20.5\%), Agriculture, Poultry Farming, Fishing etc. (8.7\%), and Wholesale and Retail Trade, etc., (about 4.00\%).

In the last 10 years in Pakistan, in terms of gross domestic product (GDP), the share of manufacturing sector rose from 14.7 percent in 1999-2000 to 18.7 percent in 2010-11. On the other side, according to shah investment in this sector a "booster" of an economy, according to Shah (2011), has shown a decreasing trend from 2007 to 2011 (Memon \& Tahir, 2012).

There are approximately, two millions micro and small \& medium enterprises existed in Pakistan. These include 400,000 Manufacturing units, 600,000 Service sector units and 1 million Trade sector units (retailers) (Gallup cyber letter in SME in Pakistan, 2004).

Value: SMEs (Manufacturing units*) contribute approximately 34 billion Rupees per year to GDP. They constitute nearly one third (29\%) of the total value of manufacturing in the country (Gallup cyber letter in SME in Pakistan, 2004).

Employment: SMEs (Manufacturing) employ more than 1.2 million persons, whereas the total labour force in the manufacturing sector is around 1.8 million persons. Hence, they account for approximately $70 \%$ of total labour force in the manufacturing sector (Gallup cyber letter in SME in Pakistan, 2004).

Number: The number of SME (Manufacturing) in the country is over 400,000, whereas the number of all other units is less than 10,000. Hence, SMEs constitute more than $98 \%$ of total number of manufacturing units (Gallup cyber letter in SME in Pakistan, 2004). The manufacturing sector in a country like Pakistan has a great potential on promoting economic growth and competiveness. It is one of the leading sectors in Pakistan. The manufacturing sector has experienced the fluctuations over the years under different financial conditions (Memon \& Tahir, 2012).

\section{A Few Hard Facts for Malaysian and Pakistani SMEs}

The SMEs directories and their detail information need to be updated and restructured/reconstructed and re-edited in both the countries. None of the two countries SMEs institutions have proper and updated directories of SMEs of their respective countries. Like pharmaceutical manufacturers, wholesalers and constructions companies etc.

1) Lack of financing in both the countries

2) Lack of entrepreneurs in both the countries

3) Lack of training programs regarding starting up various businesses in both the countries

4) Energy crises in Pakistan 
5) Training programs should be established in both the countries

6) Women entrepreneurs should be encouraged and facilitated in both the countries

\section{Conclusion}

The aim of this study was to highlight the importance of SMEs in the development and growth of national economies. There is no doubt, that SMEs play a vital role in developed as well as developing economies equally. During related literature review, it has been found that many researchers are convinced that SMEs are crucial for the development of economies in the globe. More specifically, Malaysian and Pakistani economies are mainly based on SMEs. Therefore, Pakistani and Malaysian governments need to emphasis on the development of SMEs sector. The study would like to invite potential researchers to conduct empirical studies in Malaysia and Pakistan to understand the importance of SMEs in-depth.

\section{References}

Armstrong, C. E., \& Drnevich, P. L. (2009). Small business strategies: refining strategic management theory for the entrepreneurial and small business contexts. Atlanta Competitive Advantage Conference Paper, 29. [Online] Available: http://ssrn.com/abstract=1348632

Asia-Pacific Economic Cooperation APEC. (2010). SME market access and internationalization: Medium term KPIs for the SMEWG strategic plan. APEC Policy Support Unit.

Bizomer. (2009). [Online] Available: http://www.bizomer.com/role-of-smes-in-pakistan.html

Char, A. K., Yasoa, M. R. B., Hassan, Z., \& Muhammad, M. Z. (2010). Small and medium enterprises (SMEs) competing in the global business environment: a case of Malaysia. International Business Reseacrch, 3(1).

Dalrymple, J. F. (2004). Performance measurement for SME growth. A business profile benchmarking approach. Second World Conference on POM and 15th Annual POM Conference, Cancun, Mexico, 20.

Gallup cyber letter in SME in Pakistan, 2000-2004 (2004). [Online] Available: http://www.gallup.com.pk/News/SME_Apr_04.pdf

Goh, P. C., \& Lim, K. P. (2004). Disclosing intellectual capital in company annual reports: evidence from Malaysia. Journal of Intellectual Capital, 5(3), 500-510. http://dx.doi.org/10.1108/14691930410550426

Hashim, M. K. (2000). Business strategy and performance in Malaysian SMEs: A recent survey. Malaysian Management Review, 35(2), 1-10.

Hill, J., \& McGowan, P. (1999). Small business and enterprise development: questions about research methodology. International Journal of Entrepreneurial Behaviour \& Research, 5(1), 5-18. http://dx.doi.org/10.1108/13552559910259829 
Hin, C. W., Kadir, K. A., \& Bohari, A. M. (2013). The strategic planning of SMEs in Malaysia: Types of strategies in the aftermath of economic downturn. Asian Journal of Business and Management Sciences, 2(8), 51-59.

Hussain, I., Farooq, Z., \& Akhtar, W. (2012). SMEs development and failure avoidance in developing countries through public private partnership. African Journal of Business Management, 6(4), 1581-1589.

Khalique, M., Isa, A. H. Md. \& Shaari, J. A. N., (2011). Challenges for Pakistani SMES in a Knowledge-Based Economy. Indus Journal of Management \& Social Sciences, 5(2), 74-80.

Khalique, M., Shaari, J. A. N., Isa, A. H. Md., \& Ageel, A. (2011). The challenges faced by the small and medium enterprises (SMEs) in Malaysia: in intellectual capital perspective. International Journal of current research, 3(6), 398-401.

Khan, N. R., Awang, M., \& Zulkifi, C. M. (2013). Small and medium enterprises and human resources practices in Pakistan. International Journal of Asian Social Science, 3(2), 460-471.

Memon, M. A., \& Tahir, I. M. (2012). Size and operational performance of manufacturing companies in Pakistan; using data envelopment analysis. Journal of Information Engineering and Applications, 2(4), 2224-5782.

Mohammad, A. A. F. (2012). Sizing up Malaysia’s manufacturing SMEs-definitional implications. Journal of Statistical Modeling and Analytics, 3(1), 37-45.

Noudoostbeni, A., Yasin, N. M. \& Jenatabadi, H. S. (2009). To investigate the success and failure factors of ERP implementation within Malaysian small and medium enterprises. International Conference on Information Management and Engineering, IEEE Computer Society, 4.

Omar, S. S. B., Arokiasamy, L., \& Ismail, M. (2009). The background and challenges faced by the small medium enterprises. A human resource development perspective. International Journal of Business and Management, 4(10), 95-102. http://dx.doi.org/10.5539/ijbm.v4n10p95

Ong, J. W., Ismail, H., \& Yeap, P. F. (2010). Malaysian small and medium enterprises: the fundamental problems and recommendations for improvement. Journal of Asia Entrepreneurship and Sustainability, 6(1).

Ong, J. W., Ismail, H., \& Yeap, P. F. (2010). Malaysian small and medium enterprises: the fundamental problems and recommendations for improvement. Journal of Asia Entrepreneurship and Sustainability, 6(1).

Qureshi, J. A. (2012). Financial quota of loans for the SME sector in Pakistan: A survey in Karachi. Interdisciplinary Journal of Contemporary Research in Business, 4(5), 725-741.

Radam, A., Abu, M. L., \& Abdullah, A. M. (2008). Technical efficiency of small and medium enterprise in Malaysia: a stochastic frontier production model. International Journal of Economics and Management, 2(2), 395-408. 
Rahman, S. U. (2001). A comparative study of TQM practice and organizational performance of SMEs with and without ISO 9000 certification. International Journal of Quality \& Reliability Management, 18(1), 35-49. http://dx.doi.org/10.1108/02656710110364486

Raouf, A. (1998). Development of operations management in Pakistan. International Journal of Operations \& Production Management, 18(7), 649-650. http://dx.doi.org/10.1108/01443579810217602

Reider, R. (2008). Effective Operations and Controls for the Privately Held Business. New York: John Wiley \& Sons.

Rose, R. C., Kumar, N., \& Yen, L. L. (2006). Entrepreneurs success factors and escalation of small and medium-sized enterprises in Malaysia. Journal of Social Sciences, 2(3), 74-80. http://dx.doi.org/10.3844/jssp.2006.74.80

Saleh, A. S., \& Ndubisi, N. O. (2006). An evaluation of SME development in Malaysia. International Review of Business Research Papers, 2(1), 1-14.

Shah, A. (2011). Pakistan Economic Survey, 2010-2011. Manufacturing and Mining. Government of Pakistan. Ministry of Finance.

Sim, A. B. (1991). Turnaround for small businesses- A synthesis of determinants for action research, with reference to Malaysia. Malaysian Management Review, 26(3), 15-22.

Sim, A. B., \& Yap, T. H. (1997). Strategy types in Malaysian industrial companies. Malaysian Management Review, 32(4), 1-10.

SME Annual Report Malaysia (2011/2012).

SME Corp. Malaysia. (2013). [Online] Available: http://www.smecorp.gov.my/vn2/node/37

SME Corp. Malaysia. (2014). [Online] Available: http://www.smecorp.gov.my/vn2/

SME Corp. Malaysia. (2014). [Online] Available: http://www.smeinfo.com.my/index.php?option=com_content\&view=article\&id=1415\&Itemi $\mathrm{d}=1312$ \&lang=en

SME International Malaysia. (2013). [Online] Available: http://smeinternational.org/sme-information/developing-malaysian-smes.

SMEDA. (2013). [Online] Available: http://www.smeda.org/index.php?option=com_fsf\&view=faq\&catid=3\&faqid=48.

SMEDA. (2013). [Online] Available: http://www.smeda.org/index.php?option=com_content\&view=article\&id=2\&Itemid=10.

Syed, A. A. S. G., Ahmadani, M. M., Shaikh, N., \& Shaikh, F. M. (2012). Impact analysis of SMEs sector in economic development of Pakistan: a case of Sindh. Journal of Asian Business Strategy, 2(2), 44-53. 


\section{Macrothink}

Business and Management Horizons

ISSN 2326-0297

2014, Vol. 2, No. 2

Veskaisri, K., Chan, P., \& Pollard, D. (2007). Relationship between strategic planning and SME success: empirical evidence from Thailand. International DSI/Asia and Pacific DSI, 13.

Wiklund, J., \& Shepherd, D. (2005). Entrepreneurial orientation and small business performance: a configurational approach. Journal of Business Venturing, 20, 71-91. http://dx.doi.org/10.1016/j.jbusvent.2004.01.001

Wong, K. Y., \& Aspinwall, E. (2004). Characterizing knowledge management in the small business environment. Journal of Knowledge Management, 8(3), 44-61. http://dx.doi.org/10.1108/13673270410541033

\section{Copyright Disclaimer}

Copyright for this article is retained by the author(s), with first publication rights granted to the journal.

This is an open-access article distributed under the terms and conditions of the Creative Commons Attribution license (http://creativecommons.org/licenses/by/3.0/). 